\title{
ガイドラインを参考にした気管支喘息治療のコッ
}

\author{
滝澤 始
}

〔日内会誌 96:2822～2828，2007〕

はじめに

我が国を含む先進諸国において気管支喘息の 増加は明らかであり, その原因の究明や予防対 策, そして適切な治療は社会的にも重要な課題 となっている，喘息のよりよい治療と管理を実 現するためには, 担当医・患者間のパートナー シップはもちろんのこと, 吸入療法やコントロー ルについての看護師, 薬剂師の役割が大きい. ガイドラインの作成と普及への努力は, まさに こうした要求に答えるものである. 1993 年に日 本アレルギー学会により,「アレルギー疾患治療 ガイドライン」として初版が刊行されたのを皮 切りに, 1998 年の「喘息予防・管理ガイドライ ン」(「JGL’98」), 2003 年には「JGL2003-1998 改訂第 2 版一」(「JGL2003」)が刊行された。この 間, 国際的には 1995年にWHO/NHLBI（National Heart, Lung, and Blood Institute) ワークショッ プレポートして「Global Initiative for Asthma (GINA) (GINA2002)」が刊行された. 2007 年 9 月時点では, 昨年改定されたJGL2006および GINA2006 が最新版である.

この間, 吸入ステロイドの普及に伴って外来 予定外受診 - 救急入院の減少, 喘息死亡数の減 少などがみられており，これらガイドラインの 整備と普及の貢献が考えられる一方, アンケー トによると吸入用ステロイド薬の普及率は十分

たきざわ はじめ: 帝京大学附属溝口病院第四内科
に高いとはいえず, 標準的治療法のさらなる周 知徹底の必要性が叫ばれている. 本稿では,「気 管支喘息診療のコッ」を, JGL2006 ${ }^{1)}$ に従い概説 する.

ここで強調したいことは,「ガイドライン, 活 用しなけりゃただの紙束」ということである. 何度も見直し擦り切れるようにして欲しい, 可 能なら患者にもそのサマリーを随時お見せする といい. と同時に「ガイドラインはあくまでガ イドライン＝指針にすぎない, それ以上でもそ れ以下でもない」ということも事実である. 要

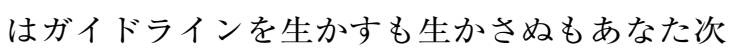
第というわけである.

\section{1. 治療目標について}

表 1 にあるように, 健常人と変わらない日常 生活および発育, 正常に近い肺機能, 十分な睡 眠, 発作からの解放, 喘息死の回避, 治療薬の 副作用のないこと, という従来の目標に加え, 初めて気道リモデリングの予防が揭げられた. この背景には, 喘息の臨床経過における気道り モデリングの重要性が様々な知見から裏付けら れたことがある。実際，気道リモデリングのよ く用いられる指標である基底膜下の線維性肥厚 の程度は, 気道過敏性や重症度とよい相関を示 す。また，呼吸生理学的にも気道リモデリング によって壁が肥厚した気管支では, 同程度の気 管支収縮がはるかに大きな気道抵抗の増加をも たらすことが明らかにされている，副腎皮質ス 
表 1. 喘息治療の目標

1 健常人と変わらない日常生活が送れること 正常な発育が保たれること

2 正常に近い肺機能を維持すること PEFの変動が予測值の 10\% 以内 PEF が予測值の $80 \%$ 以上

3 夜間や早朝の咳や呼吸困難がなく十分な夜間睡眠 が可能なこと

4 喘息発作が起こらないこと

5 喘息死の回避

6 治療薬による副作用がないこと

7 非可逆的な気道リモデリングへの進展を防ぐこと

[喘息予防・管理ガイドライン 2006］

テロイド吸入による早期介入治療の前向き大規 模試験で, 有意に重症発作の危険度が減少した。 これらの知見から, 早期のステロイド吸入治療 が気道リモデリングの予防や治療に有効である 可能性が高いと考えたわけである.

\section{2. 問診と日常生活の指導のコッ}

ついおろそかにされがちであるが，特に初診 時にチェックリストを作り, 以降の指導に役立 てたい。この患者との最初の出会いで十分時間 をかけて問診と指導を行うことにより「この医 師はマイドクターになってくれる」という信頼 関係を築きやすくなり, 以後の治療が大変スムー ズになる。

具体的には,

（1）室内塵ダ二曝露の状況と抑制策 (例えば, ふとんやマットレス，カーテン，じゅうたん， 床の状況や誰が掃除をするかなど）

（2）喫煙と禁煙指導，女性では特に妊娠中お よび子供の近くでの禁煙

（3）職業歴（職業喘息の可能性とともに職場 ストレスなど）や生活歴（沿道の交通量や大気 污染状況)

（4）ソバなどの特殊なアレルゲンに関する チェック

（5）いわゆるアスピリン喘息（非ステロイド
性抗炎症薬で誘発されないか)

（6）他のアレルギー性疾患（アトピー性皮膚 炎，アレルギー性鼻炎など）や副鼻腔炎などの 上下気道疾患の合併, など.

（7）重症例，難治性ではアレルギー性肉芽腫 性血管炎やアレルギー性気管支肺アスペルギロー シスなどのチェックとともに「本当に喘息か？」 という原点にもどったチェック

そして生活指導では，これらを中心に特にウ イルス性呼吸器感染症, 薬物・食品添加物, 職 業, 運動, 過換気, 気象変化, 強い情動負荷 ( ス トレス)などについて時期にあった指導を行う. またインフルエンザ予防接種の励行と肺炎球菌 予防接種の適応の検討も忘れない.

\section{3. 喘息治療薬の選択のコッ}

抗喘息薬とは, 喘息治療に必要なすべての薬 剂をさす。そして，処方箋を書くときには，「今 自分は, 長期管理薬を書いているのか, 発作治 療薬を書いているのか」を意識する。つまり，

（1）長期管理薬（コントローラー：長期管理 のために継続的に使用する薬郕）：発作予防は もちろんのこと気道リモデリング予防・治療ま で目標としている薬物

（2）発作治療薬（リリーバー：発作治療のた めに短期的に使用する薬剂）：とりあえず患者 自身の判断で行って欲しい治療で，その結果ど うだったら医師に受診する必要があるかを同時 に説明するべき薬物

に分けて検討し決定するべきである．さらに， それぞれの意味づけを患者に説明し理解しても らうことが治療の第一歩となる.

ここではその大まかな要点を整理する.

\section{回副腎皮質ステロイド薬}

長期管理薬の第一選択である.その理由は, 気管支喘息に特徽的なアレルギー性気道炎症を 抑制する最も強力な薬剂だからである。これに より, 臨床的には喘息発作の消失, 日常的な呼 
吸機能の改善ないし正常化をもたらし，患者の 生活の質を格段に向上させ，日常生活を制限無 く快適にすごせるようにする．わが国の吸入ス テロイド薬の使用量が増加するにつれて，喘息 による死亡者数が減少している (2006 年は 2,770 人).

○その剂型からみた優先順位は, 高い局所到 達とより少ない全身副作用から，吸入用ステロ イド薬が第一位である.

○現在わが国において使用できる吸入用ステ ロイド薬は, プロピオン酸フルチカゾン（商品 名：フルタイド) ドライパウダーインヘラー (FPDPI）(デイスカスおよびデイスクヘラー), フル タイドのHFA製剤（FP-HFA）(フルタイドエ アー), ブデソニド・ドライパウダーインヘラー (BUD-DPI) (商品名：パルミコート), プロピオ ン酸ベクロメタゾンの代替フロンHFAを用いた エアゾール製剤(商品名：キュバール)，フルタ イドと長期時間作用性 $\beta_{2}$ 受容体刺激薬サルメテ ロールの合剤（商品名：アドエア）およびシク レソニドのエアゾール製剤（商品名：オルベス コ）である.

○各製剤の特徵をひと筆書きすると

(以下わかりやすいので商品名で記載)

○フルタイド・デイスカス：標準的. 吸入し やすい. 残数確認空つき. 嗄声やのどの刺激感 がやや多い.

○パルミコート：高齢者, 低肺機能でも吸い やすい. FDAカテゴリーのBランクで妊娠中や妊 娠可能な女性に使いやすい

○キュバール：粒子が小さいので末梢気道や 肺への沈着率が高く, カンジダ症少ない. スペー サーはしたほうがよい.

○フルタイドエアー：エアゾール製剤を希望 する人．スペーサーはしたほうがよい

○アドエア：合剤ゆえこれひとつでよいとい う利便性. 使用の徹底が期待できる. 現在は一 回 2 週間分のみ処方可能である.

○オルベスコ：一日 1 回でよい. 粒子が小さ
いので末梢気道や肺への沈着率が高い. 肺での み活性化するので口腔内の副作用が少ない， ス ペーサーは不要である.

○いつ使用するか：軽症持続型（ステップ 2) つまり毎週のように発作あり, 以上で使用. 量 はステップに応じて使用する（表 2,3 ）.

○早期介入 (early intervention)の考えからは ステップ 1 (軽症間欠型)でも低用量ステロイド 吸入を行ってよい.

\section{口長時間作用型 $\beta_{2}$ 受容体刺激薬}

強力な気管支平滑筋弛緩作用を有し, 気管 支拡張薬として用いられるが，長期使用による 抗炎症作用は認められない。従って吸入用ステ ロイド薬との併用が原則である.

○わ゙国で使用可能な薬剤は, 吸入薬は一種 のみ（キシナホ酸サルメテロール，商品名：セ レベント)ドライパウダー製剤(デイスクヘラー, デイスカス).最近前述したフルタイドとの合剤 (商品名：アドエア)が発売された。わが国独自 のものとして貼付剤（塩酸ツロブテロール，商 品名：ホクナリンテープ）があり，他にわが国 で伝統的に用いられてきた経口薬が数種類ある.

○吸入薬が世界標準である.1 日 2 回使用で十 分な気管支拡張を示す。副作用も少ない.

貼付薬は 1 日 1 回貼ることで安定した気管 支拡張効果が得られる。吸入薬の使用が困難な 例では良い適応である。しかし，皮膚局所のか ぶれなどに注意し，アトピー性皮膚炎合併例で は注意が必要である。

○経口薬は全身性副作用特に動悸，手のふる えなどに注意が必要であり，新規に用いられる ことは少ない。

○吸入ステロイドの単独治療で十分コントロー ルが得られない場合，ステロイド増量よりも長 時間作用型 $\beta_{2}$ 受容体刺激薬吸入剂の併用が優れて いることが明らかとなっている.

ロロイコトリエン拮抗薬

○システイニルロイコトリエン (CysLT) 1 受容体に結合することによりCysLTの作用を抑 
表 2. 治療前の臨床所見による喘息重症度の分類（成人）

\begin{tabular}{|c|c|c|c|c|c|}
\hline 重症度 1) & & $\begin{array}{l}\text { ステップ } 1 \\
\text { 軽症間欠型 }\end{array}$ & $\begin{array}{l}\text { ステップュ } \\
\text { 軽症持続型 }\end{array}$ & $\begin{array}{l}\text { ステップ } 3 \\
\text { 中等症持続型 }\end{array}$ & $\begin{array}{l}\text { ステップ } 4 \\
\text { 重症持続型 }\end{array}$ \\
\hline \multirow{4}{*}{$\begin{array}{l}\text { 喘息症状の } \\
\text { 特徵 }\end{array}$} & 頻度 & 週 1 回末満 & $\begin{array}{l}\text { 週 } 1 \text { 回以上だが } \\
\text { 毎日ではない }\end{array}$ & 毎日 & 毎日 \\
\hline & \multirow{2}{*}{ 強度 } & 症状は軽度で短い & $\begin{array}{l}\text { 月 } 1 \text { 回以上日常 } \\
\text { 生活や睡眠が妨 } \\
\text { げられる }\end{array}$ & $\begin{array}{l}\text { 週 } 1 \text { 回以上日常 } \\
\text { 生活や睡眠が妨げ } \\
\text { られる }\end{array}$ & 日常生活に制限 \\
\hline & & & & $\begin{array}{l}\text { 短時間作用性吸入 } \\
\text { 刺激薬頓用が } \\
\text { ほとんど舟日要 }\end{array}$ & $\begin{array}{l}\text { 治療下でもしば } \\
\text { しば増悪 }\end{array}$ \\
\hline & 夜間症状 & 月につ 回未満 & 月 2 回以上 & 週 1 回以上 & しばしば \\
\hline \multirow{2}{*}{$\begin{array}{l}\text { PEF } \\
\text { FEV }_{1.0^{2)}}\end{array}$} & \%FEVı.о, \%PEF & $80 \%$ 以上 & $80 \%$ 以上 & $\begin{array}{c}\text { 60\% 以上 } \\
\text { 未満 }\end{array}$ & 60\% 未満 \\
\hline & 変動 & 20\% 未満 & $20 \sim 30 \%$ & 30\% を超える & 30\% を超える \\
\hline
\end{tabular}

1) いずれか 1 つが認められればそのステップと判断する.

2）症状からの判断は重症例や長期罹患例で重症度を過小評価する場合がある. 呼吸機能は気道閉塞の程度を客観的に示 し，その变動は気道過敏症と関連する。 \% FEV $1.0=\left(F E V_{1.0}\right.$ 測定值/FEV 1.0予測值 $) \times 100, \% P E F=(P E F$ 測定値 $/$ PEF予測値または自己最良値 $) \times 100$

[喘息予防・管理ガイドライン 2006］

表 3. 各吸入ステロイド薬のステップ別の推奨量

\begin{tabular}{|c|c|c|c|c|}
\hline 薬剤名 & $\begin{array}{l}\text { ステップ } 1 \\
\text { (最低用量) }\end{array}$ & $\begin{array}{c}\text { ステップュ } \\
\text { (低用量) }\end{array}$ & $\begin{array}{c}\text { ステップ } 3 \\
\text { (中用量) }\end{array}$ & $\begin{array}{c}\text { ステップ } 4 \\
\text { (高用量) }\end{array}$ \\
\hline BDP-HFA & 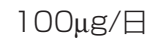 & 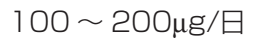 & 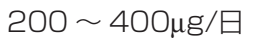 & $400 \sim 800 \mu g / 日$ \\
\hline FP-HFA & 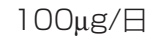 & 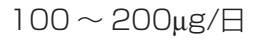 & 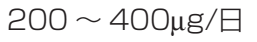 & $400 \sim 800 \mu g / 日$ \\
\hline FP-DPI & 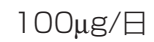 & $100 \sim 200 \mu g / 日$ & 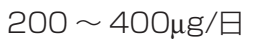 & $400 \sim 800 \mu g / 日$ \\
\hline BUD-DPI & 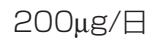 & $200 \sim 400 \mu g / 日$ & 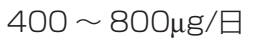 & $800 \sim 1,600 \mu \mathrm{g} /$ 日 \\
\hline
\end{tabular}

[喘息予防・管理ガイドライン 2006]

制し，気管支拡張作用に加え気道炎症を抑制す る効果をもつ.

○長期管理薬として単独で使用した場合吸入 用ステロイド薬に劣る.

○吸入用ステロイド薬の単独治療で十分コン トロールが得られない場合, ステロイド増量よ りもロイコトリエン拮抗薬との併用が優れてい ることが明らかとなっている.ただし, 高用量 ステロイド吸入群での併用効果は認められなかっ た。

吸入用ステロイド薬との併用効果は長時間 作動性 $\beta_{2}$ 刺激薬吸入剂に比較して肺機能改善効果 は劣るものの, 気道炎症抑制効果は優れている.
○運動誘発性喘息に有効である。

○アスピリン喘息に有効である.

OResponderとnon-responderがはっきり分か れることが多く, 無効例では漫然と継続しない.

○アレルギー性鼻炎にも有効であり，特に鼻 閉症状に有効である。ただし，保険適応がある のはプルンルカストのみである.

口徐放性テオフィリン薬

○かつてのように高用量で血中濃度を高く保 つのではなく, $8 \mu \mathrm{g} / \mathrm{ml}$ 程度の低濃度で気道への 抗炎症作用が明らかにされている.

○安価である。長い使用経験がある.

○ややさじ加減を要する。 また使用中の患者 
では発作時にテオフィリン薬を点滴するとき注 意が必要である.

\section{4.「JGL2006」からみた喘息治療管理の 実際}

（1）長期管理における吸入用ステロイド薬の 使い方

本ガイドラインでは， ステップ 2 以上の持続 型喘息に対する長期治療の第一選択となる．初 回の用量について，従来通り段階的薬投与プラ ンを推奨しており（表 2), 喘息の重症度に応じ て行うように勧めている。 そして, 改善と安定 が少なくても 3 カ月以上みられたらステップダ ウンし，逆に悪化または不十分な場合はステッ プアップするとしている。この際，あらかじめ より高用量から開始するステップダウン方式に 関しては明らかな記載はない。 ガイドラインに 明記されてはいないが，ステロイド吸入薬の用 量の合言葉は,「ステップアップはすみやかに, ステップダウンはゆっくりと」である.

これもガイドラインにはないが，吸入ステロ イド療法を成功させるための「コッ」は以下の ようであると思われる。

第一は, ステロイド吸入療法の効果を, 多少 大げさでもいいから患者に十分PRすること.「こ れこそ世界標準です」「世界中が認めたオンリー ワンです」「この治療で喘息治療に革命が起きた のです!」どんな表現でもいいので，その方の 心に最もアピールする表現で強調したい.

第二に，喘息日記やピークフローメータによ るモニタリングや最近では自己評価テスト (asthma control test, ACTなど) を通じて, 病 状の改善を患者自身に客観的に納得いただく.

第三は，どれから用いるかで，これにはそれ ぞれに考え方があってよいが, 私見を述べると， いくら代替フロンでもいつまでも使用できない かもしれないので，これから初めて吸入用ステ ロイド薬を開始する方には，まず，ドライパウ
ダー型（MDI）を勧める.すなわち，フルタイ ド・デイスカスかブデソニドである.フルタイ ドでは乳糖が入っていて咳き込みが問題になる こともあるが逆に吸入の実感があっていいとい う方もいる。一方，これまでフロンを用いた定 量的なハンドネブライザーになれている方, 特 に高齢者では製剤変更が混乱を招く恐れがあっ たり，その薬剤への信頼感が治療を継続する上 でよりどころとなっている場合は, 代替フロン を用いるキュバールやフルタイドエアーに変更 してもよい. アドェアはステップ 3 以上では基 本処方になる可能性が大きい. オルベスコは 1 日 1 回ですみ, かつ末梢気道から肺への沈着率 が良好であることが魅力である.

第四は，吸入のテクニックである，それぞれ の製剂で全く異なるので，各社が配っているパ ンフレットなどを利用して，そして院外薬局の 利点を最大限に活用していただき，各個人にあ わせた指導をお願いしたい.どのくらい上手に 吸入できているかが，有効性を決定する.

第五は，経口ステロイド薬の適切な使用であ る. 経口ステロイド薬をよく利用する場面は 2 つある。ひとつは, 治療開始の時点で, 短期の 経ロステロイド療法（特に 1 週間以内）は副作 用もほとんどなく, 病状を改善し, 良好な信頼 関係の成立，患者の治療意欲を高めるうえでも 有益である。ただし，即効性はないので，必ず 「すぐは効きませんよ.2，3 日して効いてきます よ」と伝えること．経口ステロイド薬のもうひ とつの出番は, 増悪時で, 症状出現や, ピーク フローが低下してきたとき，いち早く自己判断 で服用できるように，あらかじめ患者ごとに指 示しておく. 結果的に時間外受診や入院を防げ る.

（2）併用薬の考え方

一般に, 吸入用ステロイド薬で不十分な場合, その量を上げるよりも, 長時間作用型の気管支 拡張薬やロイコトリエン拮抗薬を加えたほうが 効果は大きいといわれている.「JGL2006」1)では, 
表 4. 現在の治療を考慮した喘息重症度の分類（成人）

\begin{tabular}{|c|c|c|c|c|}
\hline & \multicolumn{4}{|c|}{ 現在の治療ステップ } \\
\hline 現在の治療における患者の症状 & ステップ 1 & ステップ2 & ステップ 3 & ステップ 4 \\
\hline $\begin{array}{l}\text { ステップ 1：軽症間欠型相当 } \\
\text { ○症状が週 } 1 \text { 回未満 } \\
\text { 症状は軽度で短い } \\
\text { の夜間症状は月に 1〜 2 回 }\end{array}$ & 軽症間欠型 & 軽症持続型 & 中等症持続型 & 重症持続型 \\
\hline $\begin{array}{l}\text { ステップ2：軽症持続型相当 } \\
\text { ○症状は週 } 1 \text { 回以上, しかし毎日ではない } \\
\text { 月 } 1 \text { 回以上日常生活や睡眠が妨げられる } \\
\text { ○夜間症状が月 } 2 \text { 回以上 }\end{array}$ & 軽症持続型 & 中等症持続型 & 重症持続型 & 重症持続型 \\
\hline $\begin{array}{l}\text { ステップ } 3: \text { 中等症持続型相当 } \\
\text { O症状が毎日ある } \\
\text { 短時間作用性吸入 } \beta 2 \text { 刺激薬がほとんど } \\
\text { 毎日必要 } \\
\text { 週 } 1 \text { 回以上日常生活や睡眠が妨げられる } \\
\text { 夜間症状が週 } 1 \text { 回以上 }\end{array}$ & 中等症持続型 & 重症持続型 & 重症持続型 & 重症持続型 \\
\hline $\begin{array}{l}\text { ステップ } 4: \text { 重症持続型相当 } \\
\text { の治療下でもしばしば増悪 } \\
\text { の症状が毎日 } \\
\text { の日常生活に制限 } \\
\text { のしばしば夜間症状 }\end{array}$ & 重症持続型 & 重症持続型 & 重症持続型 & 最重症持続型 \\
\hline
\end{tabular}

[喘息予防・管理ガイドライン 2006］

いずれのステップにおいても，テオフィリン徐 放製剂, 長時間作用型 $\beta_{2}$ 刺激薬やロイコトリエン 拮抗薬の記載に優先順位をつけていないが，こ の点は, GINA2006 とは明らかに異なっている. ステロイド薬と長時間作用型 $\beta_{2}$ 刺激薬との吸入合 剤アドエアが販売されたことにより，わが国で も併用療法の基本的処方になることが予想され る.

（3）現在の治療を考慮した重症度分類 (表 4) 初回の治療開始時には表 2 は極めて有用であ るが，例えば低用量の吸入用ステロイド薬のみ でコントロール良好な症例と高用量の吸入用ス テロイド薬に長時間作用型 $\beta_{2}$ 刺激薬さらにロイコ トリエン拮抗薬で同様のコントロール状態の症 例とで同じ重症度というのは不合理である。そ こで, 表 4 のような現在の治療状況を考慮した 重症度分類が作られた。ただ，これをどう実地 臨床で役立てていくかは課題として残っている.

\section{5. 今後の課題}

「JGL2006」では，国際的に認知されている $\lceil$ GINA2002」との整合性を意図して改訂作業が 進められた。気管支喘息治療における吸入ステ ロイド薬の重要性は広く認められているにもか かわらず，最近の電話調査によるとわが国にお ける使用の実態は諸外国よりもずっと低い頻度 であり，実地医家，患者両者ともまだまだ認識 が不足している，喘息の標準的な治療があまね く行われ，喘息死の悲劇や日常生活の制限から 多くの喘息患者が開放されるためにも本ガイド ラインを普及させる努力が, 刊行にも増して重 要と考えられる. 今回は詳述しないが, JGL2006 のあとに発表されたGINA2006では従来の重症度 分類に基づく段階的治療法（いわば医師が主体 となる評価法）から, 患者主体の評価法と治療 選択へ，大きくシフトした。すなわち，コント 
ロールのよしあしを，自己評価に基づいて「コ ントロール良好 (total control)」,「部分的コント ロール (well control)」,「コントロール不良」に 分け，これに基づいて行うことにしている。 そ のため一見するとJGL2006 との相違が大きくなっ た感があるのは否めない. 今後のJGLのさらなる 改訂においては, このGINA2006 との整合性をど う図るかという課題とともに, これらの視点か らのわが国のEBM(evidence-based-medicine)を 蓄積することが望まれる。

おわりに

長らく「抗喘息薬後進国」であったわが国に
おいてもほぼすべての種類の気管支喘息治療薬 の使用が使用可能となった。ささらは，欧米で は使用されていない貼付薬もあり，各種の吸入 ステロイド薬との併用による個々の患者に応じ た薬物治療プランが可能になったといえよう。 今後こうした併用薬剤の適切な選択, 適応患者 の選別，リモデリング予防効果等について，わ が国発の臨床研究報告がされることが重要であ り，今後内科専門医の果たすべき役割は大変大 きいと思われる。

文献

1）「喘息予防・管理ガイドライン 2006」作成委員：喘息予 防・管理ガイドライン 2006. 協和企画，東京， 2006. 